\title{
Stress faced by adolescents and coping strategies used to face
} stress.

\author{
Priyanka $^{1}$, Kshipra $^{2}$ \\ I'Assistant professor, Department of Home Science, Khwaja Moinuddin Chishti Urdu, Arabi-Farsi University, \\ Lucknow, India)
}

\begin{abstract}
The present study was conducted to assess overall stress among late adolescent students. The study is based upon sample of 120 late adolescents age 17 to 20 years. Standardized scale for stress by Vijay Laxmi, Shrutinarayan published from Agra Psychological cell was used for the study. Four dimensions of stress that is Pressure, Physical Stress, Anxiety, and Frustration were studied. A check list of coping strategies was prepared by the researcher and respondent's response was tabulated. Results showed majority of adolescents to be under moderate level of stress and 20\% under high stress. Further in four dimensions majority young adults reported for high physical pressure and anxiety whereas pressure and frustration was found to be moderate. The most common copying strategy appeared in present research was watching television, movies, music, games, internet chatting etc. This reveals that diversion or distraction is the most common strategy that adolescents find convenient to use. Thus adolescents using entertainment methods may get relief for that particular time but frequency of stress \& its reoccurrence chances are more. Better options like solving problem through cognitive approaches like introspecting oneself, planning information, seeking counselor, elders was absent in adolescents.
\end{abstract}

Keywords - Stress, pressure, anxiety, adolescents, coping strategies.

\section{INTRODUCTION}

Stress is characterized by feelings of tension, frustration, worry, sadness and withdrawal that commonly last from a few hours to a few days. Psychological stress is a peculiar relationship between the individual and his environment which the former deems as menacing or overflowing his well resources and endangering his well being. If he feels it is dangerous he will assess the resource he can tap on in order to cope with it and will face the situation. D.G. Byrne 2002 reported that adolescent stress is an emerging area of importance in considerations of the health of young people. Exposure to stress predicts a range of both physical and mental health problems in adolescents and relates as well to the initiation of important health risk behaviors. Stress is a part of adolescent culture. A case can be made that stress is increasing and with this increase comes consequences. An accurate conceptualization of cognitive and neurobiological changes during adolescence must treat adolescence as a transitional developmental period (Spear 2000), rather than a single snapshot in time (Casey et al. 2005). In other words, to understand this developmental period, transitions into and out of adolescence are necessary for distinguishing distinct attributes of this stage of development. Human adolescents display more depression. React more negatively to environmental change and show increased physiological symptoms in response to stress. There are wide differences in the way in which adolescent respond to stress. Some adolescents are particularly resilient and have high level coping strategies. Whereas other have difficulty attending to the requirement of the development process in which they are engaged. Doniels et. al. 1990 conducted a study on assessing life stressors and social resources among adolescents. It was found that depressed subjects reported more acute and chronic stressors and fewer social resources than did healthy subjects. Negative life events, ongoing stressors in different domains and stable social resources all contributed unique variance to the functioning criteria.

\section{METHODOLOGY}

a. Sample: The sample consists of 160 late adolescent's age group 17 to 20 . Tools Used: Interview schedule was developed for collecting demographical data of respondents. Standardized scale for stress by Vijay Laxmi, Shrutinarayan was used for data collection. The scale comprised of four dimensions of stress that is Pressure, Physical Stress, Anxiety, and Frustration. A check list for use of coping strategies was developed to collect information regarding various coping strategies used by adolescents to face stress.

1.1. Procedure: Above scale and self developed tools were used to collect data. Collected data was scored tabulated and analyzed to give adolescents stress and coping strategies. \% \& frequencies were assessed. 


\section{OBSERVATIONS AND DISCUSSIONS}

Stress and four components of stress that is pressure, physical pressure, anxiety and frustration was calculated and tabulated.

\subsection{Stress among adolescents.}

\begin{tabular}{|l|l|l|l|l|l|l|l|}
\hline S. No. & $\begin{array}{l}\text { Level of Overall } \\
\text { Stress }\end{array}$ & \multicolumn{2}{|l|}{ Girls N (60) } & \multicolumn{2}{l|}{ Boys N (60) } & \multicolumn{2}{l|}{ Total adolescents (N)120 } \\
\hline & & N & $\%$ & N & $\%$ & N & $\%$ \\
\hline 1 & HIGH & 16 & $27 \%$ & $\mathbf{2 4}$ & $\mathbf{4 0 \%}$ & $\mathbf{4 0}$ & $\mathbf{3 3 \%}$ \\
\hline $\mathbf{2}$ & MODERATE & $\mathbf{2 0}$ & $\mathbf{3 3 \%}$ & $\mathbf{2 4}$ & $\mathbf{4 0 \%}$ & $\mathbf{4 4}$ & $\mathbf{3 7 \%}$ \\
\hline 3 & LOW & $\mathbf{2 4}$ & $\mathbf{4 0 \%}$ & $\mathbf{1 2}$ & $\mathbf{2 0 \%}$ & $\mathbf{3 6}$ & $\mathbf{3 0 \%}$ \\
\hline
\end{tabular}

In the above table it is seen that majority of students i.e. $37 \%$ adolescents showed moderate stress. $33 \%$ showed high stress whereas only $30 \%$ showed low levels of overall stress. It is also seen that as compared to girls (which is $33 \%$ ) $40 \%$ boys showed moderate stress whereas $40 \%$ girls showed lower level of stress. $27 \%$ of girls and around $40 \%$ boys have shown high stress. Results show prevalence of stress among late adolescents. Thus the above table shows that majority of girls and boys face moderate stress to high levels of stress which may be due to various factors, which can be of future work. Stress and depression are serious problems for many teenagers, as the 1986 study of Minnesota high school students reveals. Although 61 percent of the students are not depressed and seem to handle their problems in constructive ways, 39 percent suffer from mild to severe depression. These young people often rely on passive or negative behaviors in their attempts to deal with problems (Garfinkel, et al., 1986).

2.2. Pressure among Adolescents.

\begin{tabular}{|l|l|l|l|l|l|l|l|l|}
\hline S. No. & $\begin{array}{l}\text { Level of } \\
\text { Pressure }\end{array}$ & \multicolumn{3}{|l|}{ Girls N (60) } & \multicolumn{2}{l|}{ Boys N (60) } & \multicolumn{2}{l|}{ Total adolescents (N)120 } \\
\hline & & N & $\%$ & N & \% & N & $\%$ \\
\hline $\mathbf{1}$ & HIGH & $\mathbf{1 2}$ & $\mathbf{2 0 \%}$ & $\mathbf{3 0}$ & $\mathbf{5 0 \%}$ & $\mathbf{4 2}$ & $\mathbf{3 5 \%}$ \\
\hline $\mathbf{2}$ & MODERATE & $\mathbf{3 4}$ & $\mathbf{5 7 \%}$ & $\mathbf{3 0}$ & $\mathbf{5 0 \%}$ & $\mathbf{6 4}$ & $\mathbf{5 3 \%}$ \\
\hline $\mathbf{3}$ & LOW & $\mathbf{1 4}$ & $\mathbf{2 3} \%$ & $\mathbf{0}$ & - & $\mathbf{1 4}$ & $\mathbf{1 2 \%}$ \\
\hline
\end{tabular}

In the above table we can see that majority of adolescents i.e.53\% undergoes moderate pressure whereas only $12 \%$ face low levels of pressure. $35 \%$ of adolescents have shown high levels of pressure. In comparison to girls (which are 20\%) 50\% boys have to deal with more pressure. It is also seen that boys do not face any kind of low level pressure only $23 \%$ girls have reported to face low level pressures The above table shows that boys either face high level of pressures than girls.

2.3 Physical Stress among adolescents.

\begin{tabular}{|l|l|l|l|l|l|l|l|}
\hline S. No. & $\begin{array}{l}\text { Level of Physical } \\
\text { Stress }\end{array}$ & $\begin{array}{l}\text { Girls } \\
\text { N }(60)\end{array}$ & \multicolumn{3}{|l|}{ Boys N (60) } & \multicolumn{2}{l|}{ Total adolescents (N)120 } \\
\hline & & N & $\%$ & N & $\%$ & N & \% \\
\hline 1 & HIGH & $\mathbf{8}$ & $\mathbf{1 3 \%}$ & $\mathbf{1 4}$ & $\mathbf{2 3 \%}$ & $\mathbf{2 2}$ & $\mathbf{1 8 \%}$ \\
\hline $\mathbf{2}$ & MODERATE & $\mathbf{1 0}$ & $\mathbf{1 5 \%}$ & $\mathbf{3 0}$ & $\mathbf{5 0 \%}$ & $\mathbf{4 0}$ & $\mathbf{3 3 \%}$ \\
\hline $\mathbf{3}$ & LOW & $\mathbf{4 2}$ & $\mathbf{7 0 \%}$ & $\mathbf{1 6}$ & $\mathbf{2 7 \%}$ & $\mathbf{5 8}$ & $\mathbf{4 8 \%}$ \\
\hline
\end{tabular}

Here $48 \%$ adolescents are showing low levels of physical stress and $18 \%$ are showing high levels of physical stress. 33\% show moderate levels. As we can see $70 \%$ girls show low level of physical stress whereas $50 \%$ show moderate level.Physical stress is often a reason for stress for adolescents as they are careless towards their health. We can also use this result for future work as nature of work and health status can be compared with the physical stress levels. If we compare girls with boys $23 \%$ boys faced high physical stress whereas only $13 \%$ girls showed high levels of physical stress.

2.4 Anxiety among adolescents.

\begin{tabular}{|l|l|l|l|l|l|l|l|}
\hline S. No. & Level of Anxiety & \multicolumn{2}{|l|}{ Girls N (60) } & \multicolumn{2}{l|}{ Boys N (60) } & \multicolumn{2}{l|}{ Total adolescents (N)120 } \\
\hline & & N & $\%$ & N & $\%$ & N & \% \\
\hline 1 & HIGH & 32 & $27 \%$ & 22 & $37 \%$ & 38 & $32 \%$ \\
\hline 2 & MODERATE & 4 & $\mathbf{3 3 \%}$ & $\mathbf{2 6}$ & $\mathbf{4 3 \%}$ & $\mathbf{4 6}$ & $\mathbf{3 8 \%}$ \\
\hline 3 & LOW & $\mathbf{2 4}$ & $\mathbf{4 0 \%}$ & $\mathbf{1 2}$ & $\mathbf{2 0} \%$ & $\mathbf{3 6}$ & $\mathbf{3 0 \%}$ \\
\hline
\end{tabular}

In the above table majority of adolescents 38\% show moderate levels of Anxiety and 32\% show high levels. $30 \%$ show low levels of Anxiety. If we see the comparison $20 \%$ boys and $40 \%$ girls face Low level of anxiety. $43 \%$ boys and $33 \%$ girls show moderate level of anxiety. $37 \%$ girls reported high anxiety and $27 \%$ showed high anxiety among girls and $37 \%$ boys showed high anxiety. We can see form the above table that boys face more 
anxiety than girls. The reason may be due to lack of confidence, proper guidance etc which can be of future work.

1.2. Frustration among adolescents.

\begin{tabular}{|l|l|l|l|l|l|l|l|}
\hline S. No. & $\begin{array}{l}\text { Level of } \\
\text { Frustration }\end{array}$ & \multicolumn{2}{|l|}{ Girls N (60) } & \multicolumn{2}{l|}{ Boys N (60) } & \multicolumn{2}{l|}{$\begin{array}{l}\text { Total adolescents } \\
\text { (N)120 }\end{array}$} \\
\hline & & N & $\%$ & N & $\%$ & N & $\%$ \\
\hline 1 & HIGH & 6 & $10 \%$ & 12 & $20 \%$ & 18 & $15 \%$ \\
\hline 2 & MODERATE & $\mathbf{1 6}$ & $\mathbf{2 7 \%}$ & $\mathbf{1 2}$ & $\mathbf{2 0 \%}$ & $\mathbf{2 8}$ & $\mathbf{2 3 \%}$ \\
\hline 3 & LOW & $\mathbf{3 8}$ & $\mathbf{6 3 \%}$ & $\mathbf{3 6}$ & $\mathbf{6 0 \%}$ & $\mathbf{7 4}$ & $\mathbf{6 2 \%}$ \\
\hline
\end{tabular}

The above table shows that the frustration level is relatively lower which is $62 \%$ and majority of boys $(60 \%)$ and girls $(63 \%)$ face only Low level of frustrations. Only 15\% adolescents face high level of Frustration. Lower levels of frustrations shows a positive aspect of the adolescents' personality. This will enable them to perform better and be happy individuals. The reasons and strategies for these lower levels of frustration can be used for future studies.

2.6 Coping strategies used by adolescents.

\begin{tabular}{|c|c|c|c|c|c|}
\hline \multirow[t]{2}{*}{ S.No. } & \multirow[t]{2}{*}{ COPING STRATEGIES } & \multicolumn{2}{|c|}{ GIRLS } & \multicolumn{2}{|c|}{ BOYS } \\
\hline & & $\mathbf{N}$ & $\%$ & $\mathbf{N}$ & $\%$ \\
\hline 1 & $\begin{array}{l}\text { Watching television, internet } \\
\text { browsing, playing video games, } \\
\text { watching movies, online chatting, } \\
\text { and social websites. }\end{array}$ & 52 & $86 \%$ & 35 & $58 \%$ \\
\hline 2 & $\begin{array}{l}\text { Physical exercise like jogging, } \\
\text { walking etc. or sports }\end{array}$ & 5 & $8 \%$ & 12 & $20 \%$ \\
\hline 3 & Going out with friends & - & & 40 & $66 \%$ \\
\hline 3 & Yoga \& Meditation & - & - & - & - \\
\hline 4 & $\begin{array}{l}\text { Visiting temples, praying } \\
\text { (religious, books). }\end{array}$ & 7 & $12 \%$ & - & - \\
\hline 5 & Day Dreaming/ sleeping & 15 & $25 \%$ & 20 & $33 \%$ \\
\hline 6 & Crying & 21 & $35 \%$ & - & - \\
\hline 7 & $\begin{array}{l}\text { Continuously thinking and being } \\
\text { worried about problems. }\end{array}$ & 32 & $53 \%$ & 20 & $33 \%$ \\
\hline 8 & $\begin{array}{l}\text { Closing oneself in room and not } \\
\text { interacting with any one. }\end{array}$ & 7 & $12 \%$ & 10 & $16 \%$ \\
\hline 9 & Smoking, tobacco, alcohol & - & - & 13 & $21 \%$ \\
\hline 10 & $\begin{array}{l}\text { Showing your anger on people } \\
\text { close to you. }\end{array}$ & 3 & $5 \%$ & 14 & $23 \%$ \\
\hline 11 & Shopping Inaccessibly & 14 & $23 \%$ & - & - \\
\hline 12 & $\begin{array}{l}\text { Sulking, brooding maintaining } \\
\text { silence, locking oneself away from } \\
\text { people. }\end{array}$ & & - & 10 & $16 \%$ \\
\hline 13 & $\begin{array}{l}\text { Talking to someone about stress. } \\
\text { Parents } \\
\text { Friends } \\
\text { Siblings } \\
\text { Teachers } \\
\text { Neighbours. }\end{array}$ & $\begin{array}{l}14 \\
3 \\
10 \\
1\end{array}$ & $23 \%$ & $\begin{array}{l}3 \\
- \\
3 \\
-\end{array}$ & $\begin{array}{l}5 \% \\
- \\
- \\
-\end{array}$ \\
\hline 14 & $\begin{array}{l}\text { Seeking information } \\
\text { through internet } \\
\text { Reading books. }\end{array}$ & $\begin{array}{l}6 \\
5\end{array}$ & $\begin{array}{l}10 \% \\
8 \%\end{array}$ & $\begin{array}{l}10 \\
- \\
\end{array}$ & $\begin{array}{l}16 \% \\
- \\
\end{array}$ \\
\hline 15 & $\begin{array}{l}\text { Developing positive thinking style } \\
\text { towards problem. }\end{array}$ & - & - & - & - \\
\hline 16 & $\begin{array}{l}\text { Introspecting and focusing on } \\
\text { finding solutions. }\end{array}$ & - & - & - & - \\
\hline 17 & $\begin{array}{l}\text { Consulting reasonable person } \\
\text { counselor or anyone else having } \\
\text { knowledge regarding problem. }\end{array}$ & - & - & - & - \\
\hline
\end{tabular}


The most common copying strategy appeared in present research was watching television, movies, music, games, internet chatting etc. about $86 \%$ boys and $58 \%$ girls used these methods during stress. This reveals that diversion or distraction is the most common strategy that adolescents find convenient to use. De Anda and bradely in 1997 found that coping strategies today adolescents employ such as (diversion \& distraction) Ex. T.V, Music, and Reading etc., don't help teenagers deal with stress. Another behavior distraction method used by adolescent boys was going out with friends that is $66 \%$ boys used this strategy while $23 \%$ girls did shopping inaccessibly. Physical exercise and sports that are good in taking out pent up energy were used less that is $8 \%$ by girls and $20 \%$ by boys. $12 \%$ girls invested in religious activities. $25 \%$ girls and $33 \%$ boys spend their time in daydreaming or sleeping to avoid stress. $25 \%$ girls cried to take out their negative emotions where as none of the boys reported for it. Majority that is $53 \%$ girls and $33 \%$ boys reported to continuously think about problem and worry. $12 \%$ girls and $16 \%$ boys reported for isolating themselves from others during stress. $21 \%$ boys reported to use alcohol, tobacco etc. $23 \%$ boys reported to show displacement of their stress in form of anger on others while 5\% girls did that. Positively $23 \%$ of girls communicated to others for their stress while only $5 \%$ boys did so. $10 \%$ girls and $16 \%$ boys took information from books and internet to resolve their problem. No other initiative or approach was done for problem solving.

\section{CONCLUSION}

The above study revealed that young adults or late adolescent have shown moderate to high level of stress. Among the components of stress it was found that physical stress and anxiety was more than pressure and frustration. Olah, Attila, et al 1989 investigated that distraction \& escape coping strategies lead to reoccurrence of stress comparing to constructive coping strategies. Thus adolescents using entertainment methods may get relief for that particular time but frequency of stress \& its reoccurrence changes are more. Better options like solving problem through cognitive approaches like introspecting oneself, planning information seeking counselor, elders was absent in adolescents. The study revealed majority were using coping strategies of distraction, avoiding, dislocation, isolation etc. very few reported for good techniques as problem solving and relaxation techniques like yoga meditation etc. Boys used displacement getting angry on others, going out with friends but did not preferred conversation or sharing. They did not ventilate their feelings by crying or talking. Girls to some extent had conversation with family and friends. Few have started taking advice from internet. Petersen 1993 found that the level of life meaning fullness negatively correlates with experienced level of daily stress. In several theories, life meaning is considered and important source of positive coping and stress management. Harlow New Comb \& (1986) found that adolescents with a lower sense of meaning towards life related to stress full events on a large scale by alcohol \& drug abuse. These results suggested that meaningless life was more prone towards use of alcohol and drugs. Religion, yoga \& meditation are some of the means that helps individual to understand meaning of life \& wrathfulness of life. Hardly any adolescent boys used these means. Whereas girls reported to use spiritual and religious ways of feelings peaceful when stressed. Seeking social support by referring to elders, parents, teachers, friends is an important means of coping that gives a path for ventilating feeling. But very poor use of these strategies is done by adolescents. The results revealed not a single adolescent of using yoga or meditation to relax themselves.

Scott Jr. (2004) claims that racial-related-socialization is a functional coping method instilled in adolescents from their upbringing wherein family members attempt to moderate stress by advising youth of the risks of discrimination in advance.. Thus girls had used this means while adolescents boys only shared their problems to friends not parents or others. The major reason for that is our cultural impact. Generally our society has gender stereotype that girls are soft, emotional, timid, whereas boys are hard tough, manly etc. Thus society expect when a girls cries, says her problem whereas as boy is supposed to be strong enough to be deal matters, should not be week to cry or complain to others. Thus society influenced boys have a mentality that they should not cry or complain or share their problem. They find it a matter of social prestige and question to their manhood thus keep quiet and that psychological impact leads to more stress comparing to girls. Thus results showed that adolescent's boys in case wanted information most of them (used internet but not referring to social relations around them comparing to girls who invested more on discussing with parents and friends. Surinder Tung and Jagjit (1994) reported that male used more denial and isolation than females. In present study also non productive coping strategies like continuously thinking and worrying about problem, sulking, brooding silence, lacking oneself away from people was done by most adolescent boys. Thus there is need of counseling to these young adults for better coping strategies rather than using temporary reliefs through displacement techniques.

\section{REFERENCES}

[1] Casey BJ, Galvan A, Hare TA. Changes in cerebral functional organization during cognitive development, Curr Opin Neurobiol. 15(2):2005, 239-244.

[2] De Anda and Bradely. A study of Stress, Stressors and coping strategies among middle school adolescents, Social Work In Education, 19, 1997,87-99. 
[3] Garfinkel, B., Hoberman, H., Parsons, J., and Walker, J. Adolescent Stress, Depression and Suicide: Minnesota study. Unpublished raw data, 1986.

[4] Harlow, L. L., Newcomb, M. D., \& Bentler, P. M. Depression, self-derogation, substance use, and suicide ideation: Lack of purpose in life as a meditational factor, Journal of Clinical Psychology, 42, 1986, 5-21.

[5] Olah Attila Coping behaviour in relation to frequency and intensity of anxiety provoking situations, perceptual and motar skills. American Journal of Ortho Psychology, 59, 3, 1987, 935-943.

[6] Petersen, A.C., Compas, B.E., Brooks-Gunn, J., Stemmler, M., Ey, S., \& Grant, K. E. Depression in adolescence. American Psychologist, 48, 1993, 155-168.

[7] Scott L. D., Jr. (2004). Correlates of coping with perceived discriminatory experiences among African American adolescents. Journal of Adolescence, 27, 2003,123-137..

[8] Spear LP. The adolescent brain and age-related behavioral manifestations. Neurosci Biobehav Rev., 24(4), 2000, 417-463.

[9] Surinder, Tung and Jagjit 1994 Sex differences as a measure of coping strategies. Journal of Psychological Researches, 38, 1, 1-2. 